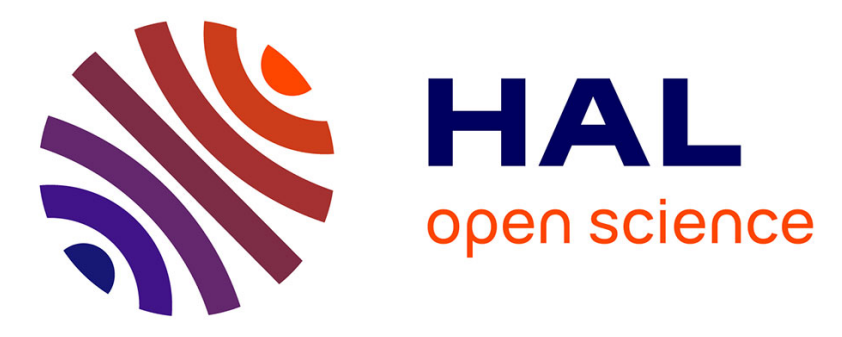

\title{
Converging Climate Sensitivities of European Forests Between Observed Radial Tree Growth and Vegetation Models
}

Zhen Zhang, Flurin Babst, Valentin Bellassen, David Frank, Thomas Launois, Kun Tan, Philippe Ciais, Benjamin Poulter

\section{To cite this version:}

Zhen Zhang, Flurin Babst, Valentin Bellassen, David Frank, Thomas Launois, et al.. Converging Climate Sensitivities of European Forests Between Observed Radial Tree Growth and Vegetation Models. Ecosystems, 2017, 21 (3), pp.1-16. 10.1007/s10021-017-0157-5 . hal-01608911

\section{HAL Id: hal-01608911 https://hal.science/hal-01608911}

Submitted on 2 Jul 2021

HAL is a multi-disciplinary open access archive for the deposit and dissemination of scientific research documents, whether they are published or not. The documents may come from teaching and research institutions in France or abroad, or from public or private research centers.
L'archive ouverte pluridisciplinaire HAL, est destinée au dépôt et à la diffusion de documents scientifiques de niveau recherche, publiés ou non, émanant des établissements d'enseignement et de recherche français ou étrangers, des laboratoires publics ou privés. 


\title{
Converging Climate Sensitivities of European Forests Between Observed Radial Tree Growth and Vegetation Models
}

\author{
Zhen Zhang, ${ }^{1,2,3 *}$ Flurin Babst, ${ }^{1,4}$ Valentin Bellassen, ${ }^{5}$ David Frank ${ }^{6}$ \\ Thomas Launois, ${ }^{7}$ Kun Tan, ${ }^{7}$ Philippe Ciais, ${ }^{7}$ and Benjamin Poulter ${ }^{2,8}$
}

\begin{abstract}
${ }^{1}$ Swiss Federal Research Institute WSL, Zürcherstrasse 111, 8903 Birmensdorf, Switzerland; ${ }^{2}$ Institute on Ecosystems and Department of Ecology, Montana State University, Bozeman, Montana 59717, USA; ${ }^{3}$ Northwest Institute of Eco-Environment and Resources, Chinese Academy of Sciences, Lanzhou 730000, China; ${ }^{4}$ W. Szafer Institute of Botany, Polish Academy of Sciences, Lubicz 46, 31-512 Karkow, Poland; ${ }^{5}$ INRA, UMR1041 CESAER, Université Bourgogne Franche-Comté, AgroSup Dijon, 21000 Dijon, France; ${ }^{6}$ Laboratory of Tree-Ring Research, University of Arizona, Tucson, Arizona 85721, USA; ${ }^{7}$ Laboratoire des Sciences du Climat et de l'Environnement, l'Orme des Merisier, Bat 701, Point courrier 129, 91191 Gif-Sur-Yvette, France; ${ }^{8}$ Biospheric Science Laboratory, NASA Goddard Space Flight Center, Greenbelt, Maryland 20771, USA
\end{abstract}

\begin{abstract}
The impacts of climate variability and trends on European forests are unevenly distributed across different bioclimatic zones and species. Extreme climate events are also becoming more frequent and it is unknown how they will affect feedbacks of $\mathrm{CO}_{2}$ between forest ecosystems and the atmosphere. An improved understanding of species differences at the regional scale of the response of forest productivity to climate variation and extremes is thus important for forecasting forest dynamics. In this study, we evaluate the climate sensitivity of aboveground net primary production (NPP) simulated by two dynamic global vegetation models (DGVM; ORCHIDEE and LPJ-wsl) against
\end{abstract}

tree ring width (TRW) observations from about 1000 sites distributed across Europe. In both the model simulations and the TRW observations, forests in northern Europe and the Alps respond positively to warmer spring and summer temperature, and their overall temperature sensitivity is larger than that of the soil-moisture-limited forests in central Europe and Mediterranean regions. Compared with TRW observations, simulated NPP from ORCHIDEE and LPJ-wsl appear to be overlysensitive to climatic factors. Our results indicate that the models lack biological processes that control time lags, such as carbohydrate storage and remobilization, that delay the effects of radial growth dynamics to climate. Our study highlights the need for re-evaluating the physiological controls on the climate sensitivity of NPP simulated by DGVMs. In particular, DGVMs could be further enhanced by a more detailed representation of carbon reserves and allocation that control year-toyear variation in plant growth.

Key words: DGVM; climate response; tree ring width; forest growth; ORCHIDEE; LPJ; NPP; carbon cycle. 


\section{INTRODUCTION}

Changing climate regimes imply uncertain risks for forest biomes that-given the long life cycle of trees-may not rapidly migrate or genetically adapt to changing environmental conditions (Lindner and others 2010). Forests are carbon sinks, meaning they store $\mathrm{CO}_{2}$ and partly mitigate the growth of anthropogenic $\mathrm{CO}_{2}$ emissions in the atmosphere (Le Quéré and others 2015). However, the sign and intensity of changes in carbon storage are likely unevenly distributed across different bioclimatic zones (Charney and others 2016), and regional scale studies are required to reduce uncertainties in our understanding of forest response to climate variability and extremes. Long-term observational data integrated with mechanistic modeling approaches can provide a unique insight into how physiological processes respond to climate over long temporal scales (Girardin and others 2008; Babst and others 2013; Rammig and others 2015).

Observational options to assess annual to centennial climate response of forests arise mainly from tree-ring records that have been extensively used to investigate energy and water constraints on tree growth (Frank and others 2015; D'Orangeville and others 2016; Girardin and others 2016). Yet, the majority of existing studies have been restricted to qualitative data on growth variability because divergent sampling schemes and the lack of complementary information on tree dimensions, stand characteristics, and management have hampered the quantification and upscaling of woody net primary productivity (NPP) from large tree-ring networks (Babst and others 2014a; Nehrbass-Ahles and others 2014). In addition, comparisons between tree rings and climate variability have mostly been performed using correlation or regression-type analyses that do not allow directly inferring causal links or a mechanistic understanding of forest climate response.

Understanding forest responses to climate change is generally made possible by mechanistic modeling approaches, many of which simulate both NPP and resource allocation to sapwood increment that can be compared to tree-ring data (Berninger and others 2004). Some models have proven particularly useful in combination with tree rings (for example, StandLEAP, (Girardin and others 2008) or to explicitly simulate them, such as MAIDEN (Misson 2004), Vaganov-Shashkin (Breitenmoser and others 2014), VS-lite (Tolwinski-Ward and others 2010) or the T-model (Li and others 2014). Application of these models at large scales is rare, however, and many require detailed site information that is infrequently available. At global scales, dynamic global vegetation models (DGVMs) are the most important and rapidly evolving tool to estimate forest NPP and its trajectory in a warmer future (Sitch and others 2015). DGVMs are thus highly relevant for global change research and decision making, but they are still subject to considerable uncertainty related to (1) model structural deficiencies (Keenan and others 2012); (2) uncertainty in model parameters (Poulter and others 2010), and (3) inconsistencies in forcing data (Poulter and others 2011). In addition, initial comparisons with a European tree-ring network (Babst and others 2013; Rammig and others 2015) have indicated that NPP estimates from DGVMs are excessively drought sensitive and that their climate response needs refinement. Yet, a thorough evaluation of the seasonality in the climate response of DGVMs remains outstanding.

Herein, we present a detailed comparison between the direction of correlations of climate and growth, and the seasonality of the temperature and precipitation response within European forests inferred from the European tree-ring network (Babst and others 2013) and DGVM estimates of NPP. For this purpose, the Organising Carbon and Hydrology in Dynamic Ecosystems (ORCHIDEE) and LundPotsdam-Jena Wald Schnee und Landschaft version (LPJ-wsl) models were used to simulate forest growth at each of the approximately 1000 tree-ring sites with a variety of meteorological datasets and soil conditions. Based on these complementary datasets, we provide: (1) direct comparisons between modeled woody NPP and observed tree-ring widths; (2) estimates of the seasonal variability in the response of woody NPP and tree-ring width to climate; (3) woody NPP anomalies during the 1959 and 1976 heat and drought extremes that notably fall outside the satellite and flux-tower eras. Based on these assessments, we discuss skills and deficiencies of state-of-the-art DGVMs to simulate long-term forest growth, and explore potential future direction to tackle the challenge for improving the structure of current DGVM.

\section{Data And Methods}

\section{Tree Ring Network}

The tree ring network contains TRW data from 36 tree species covering Europe and parts of North Africa $\left(30^{\circ}-70^{\circ} \mathrm{N} / 10^{\circ} \mathrm{W}-40^{\circ} \mathrm{E}\right)$. All 992 sites span at least the 1920-1970 periods with a sample replication greater than five series and with an ex- 
pressed population signal (EPS; a measure of how representative the sampled trees are for a theoretical population chronology) above the commonly applied threshold of 0.85 (Wigley and others 1984). The most abundant species included five widespread conifers (Picea abies, Pinus sylvestris, Abies alba, Larix decidua, Pinus cembra), three Mediterranean pine species (Pinus nigra, Pinus uncinata and Pinus mugo), and three broadleaf species (Fagus sylvatica, Quercus robur, Quercus petraea). To facilitate comparison between the two DGVMs, these species were assigned to three groups that correspond to the Plant Functional Types (PFT) used in models to describe European forests (Figure 1) based on species traits and geographical distributions. In the DGVMs, all PFTs follow the same set of governing equations (except for phenology) but have different parameter values (Krinner and others 2005). Conifer sites north of $58^{\circ} \mathrm{N}$ were classified as boreal needleleaf evergreen (BoNE), whereas all other conifer sites were classified as temperate needleleaf evergreen (TeNE). Broadleaf species sites were classified as temperate broadleaf summergreen (TeBS).

\section{Model Description}

Two ecosystem models of intermediate complexity, ORCHIDEE and LPJ-wsl were used to simulate NPP at each site of the tree ring network. In order to help assess uncertainty from meteorological forcing data and soil properties on simulated NPP, three climate datasets with different time steps and spatial resolutions, as well as two soil texture schemes were compared. Two versions of ORCHIDEE were used to make simulations: a standard version (ORCHIDEE-STD, Krinner and others 2005) and a version that represents stand dynamics by calculating the structure of individual forest stands including growth of different diameter classes and natural or management-induced thinning events (ORCHIDEE-FM, Bellassen and others 2010). We used the LPJ-wsl (Sitch and others 2003; Zhang and others 2016), with simulations performed for plant functional types based on the 'mean individual' approximation for scaling individuals to landscapes.

\section{ORCHIDEE}

ORCHIDEE calculates the $\mathrm{CO}_{2}$ exchange between the biosphere and the atmosphere on a half-hourly basis, with the formulation for leaf scale photosynthesis following the Farquhar and others (1980) model (integrated to the canopy with a light interception profile proportional to LAI) and the
Ball and others (1987) formulation of stomatal conductance (Krinner and others 2005). NPP is estimated from GPP using a "resource-based" allocation scheme where non-respired photosynthesis products are distributed to wood, roots and leaves based on climate limitations. Autotrophic respiration includes a fixed growth respiration cost (28\% of the allocatable assimilates, McCree 1974) and a temperature dependent maintenance respiration following (Ruimy and others 1996). Tree mortality in this version is a climate-independent constant background mortality factor expressed in percent of biomass. ORCHIDEE has been applied to study inter-annual climate impacts on carbon balance across northern hemisphere regions (Ciais and others 2005). Compared with ORCHIDEE-STD, the version including stand dynamics and (optionally) forest management ORCHIDEE-FM includes a statistical distribution of trees in different diameter classes in a forest stand. The ORCHIDEE-FM version also adds age-related dynamics for photosynthesis efficiency, limitation of LAI in young stands, and root-to-shoot allocation ratios. ORCHIDEE-FM has been evaluated against observations from tree to continental scale in Europe (Bellassen and others 2011). The standard runs (STD) used soil texture data from the FAO global database of Zobler (1986) that were used to define the water holding capacity at each site. The default total soil depth, which partly determines water-holding capacity, was set to $2 \mathrm{~m}$.

To test the hypothesis that modeled NPP from ORCHIDEE is more sensitive to inter-annual spring temperature variability, probably reflecting the "resource-driven" carbon allocation scheme in which trees can grow as soon as GPP is positive, we introduced a parameter to constrain the onset of NPP to reflect "sink driven" growth thresholds (Fatichi and others 2014) in ORCHIDEE. We only allowed tree growth (defined by the day when NPP $>0$ ) above a minimum monthly $T=6^{\circ} \mathrm{C}$ for all PFTs. The setting of the NPP threshold temperature is based on observations of mean growing season temperature at the cold-limited treeline (Hoch and Körner 2009), and also corresponds well with observational constraints on VS-lite growth model (Tolwinski-Ward and others 2010) from a global tree-ring analysis (Breitenmoser and others 2014). Additionally, for needleleaved evergreen PFTs, because of temporal delay in the seasonal reversal from photoinhibition to photosynthetic capacity (Nippert and others 2004), we shifted the minimum temperature at which photosynthesis takes place from -4 to $0^{\circ} \mathrm{C}$. This modified version of ORCHIDEE-FM is referred to as ORC-NPP6. 
(a)

ABAL
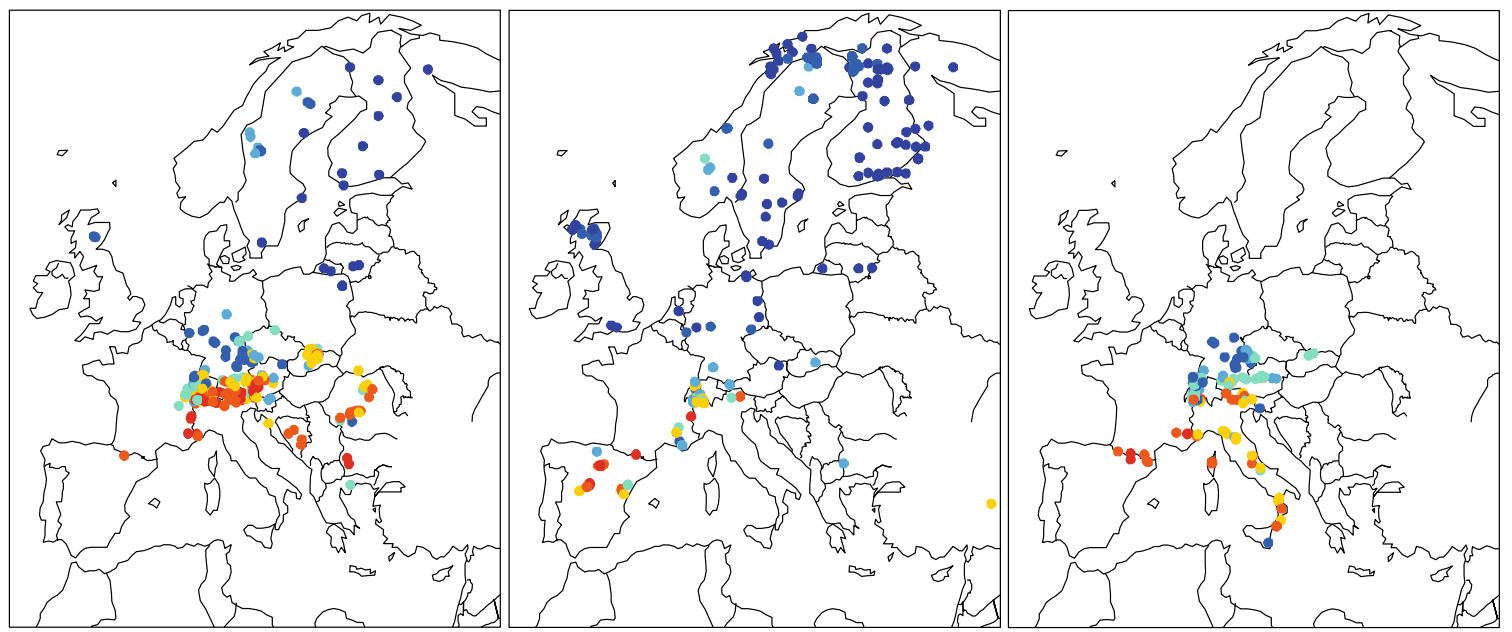

alt.(m)

LADE

PICE

other conifers
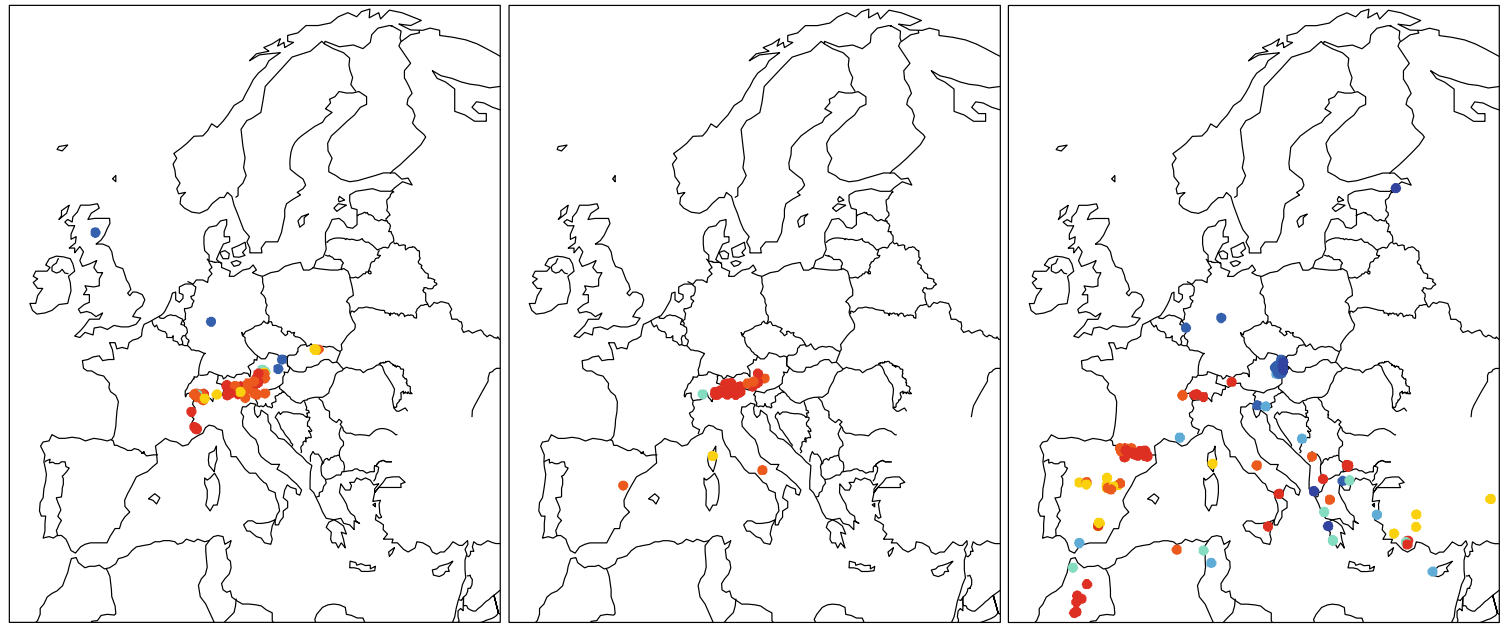

1800

2500

1500

1200

900

600
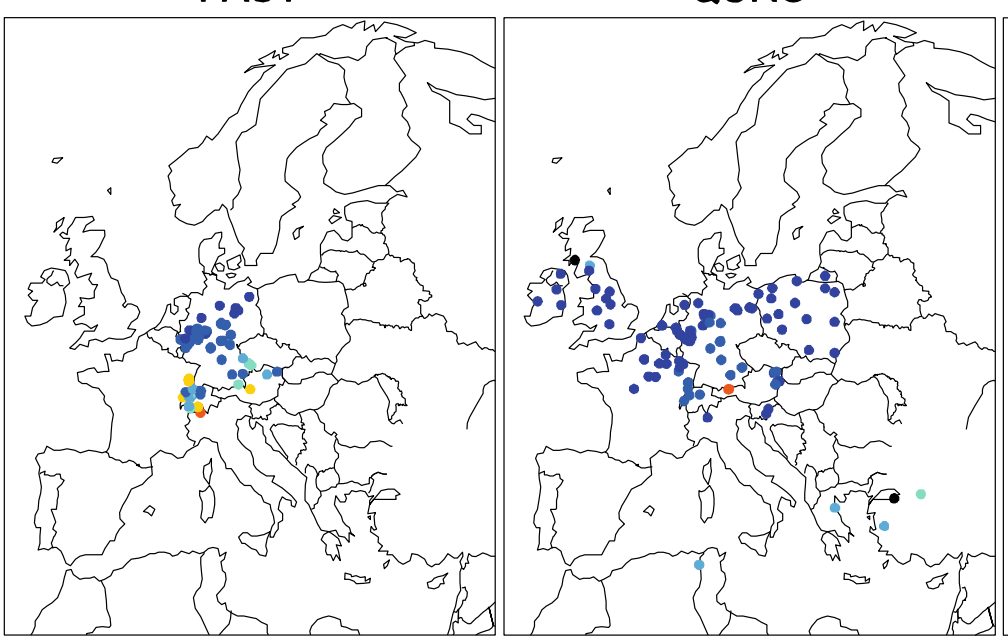

QUPE

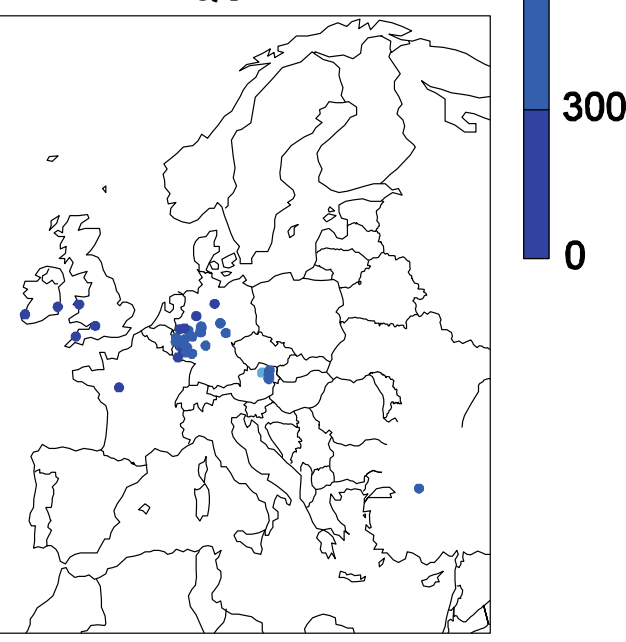

Figure 1. A Spatial distributions of tree ring network and $\mathbf{B}$ its climate-altitude space (MAT mean annual temperature, $A P$ annual precipitation). The tree ring network provides five types of conifers [Picea abies (PCAB), Pinus sylvestris (PISY), Abies alba (ABAL), Larix decidua (LADE), and Pinus cembra (PICE)], three types of broadleaves [Fagus sylvatica (FASY), Quercus robur (QURO), and Quercus petraea (QUPE)], and 'other conifers' group containing Southern European pine species (for example, Pinus nigra, Pinus uncinata and Pinus mugo). 
(b)
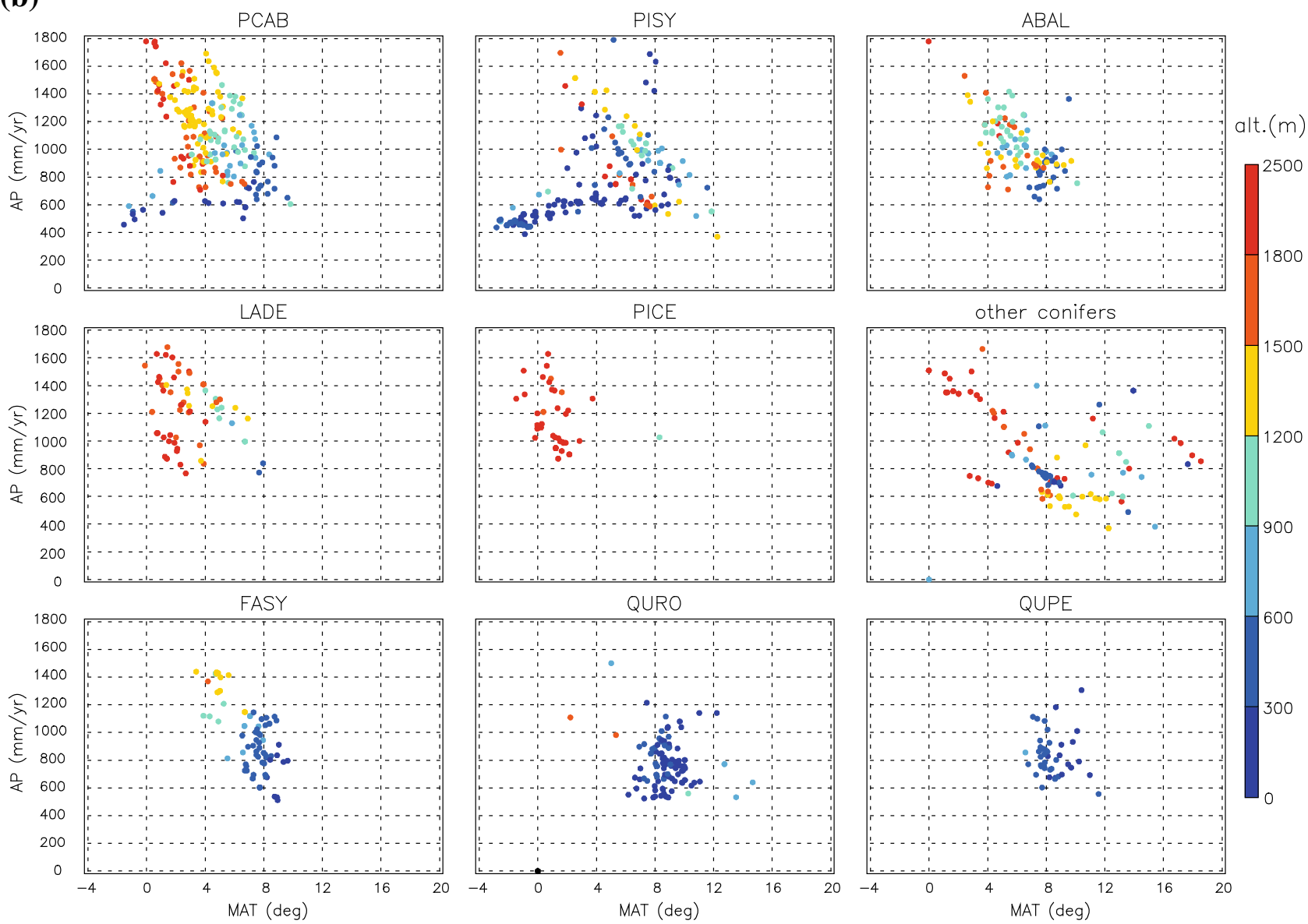

Figure 1. continued

Table 1. Summary of Dynamic Global Vegetation Models, Forcing Data, and Soil Depth Data Used for NPP Simulations

\begin{tabular}{llll}
\hline Simulation code & Model & Forcing & Soil depth \\
\hline ORC-FM-1A & ORCHIDEE-FM version & WCLIMCRU & ESDB v2.0 \\
ORC-FM-1B & ORCHIDEE-FM version & WCLIMCRU & $2 \mathrm{~m}$ \\
ORC-FM-2A & ORCHIDEE-FM version & CRUNCEP & ESDB v2.0 \\
ORC-FM-2B & ORCHIDEE-FM version & CRUNCEP & $2 \mathrm{~m}$ \\
ORC-STD-1B & ORCHIDEE-STD version & WCLIMCRU & $2 \mathrm{~m}$ \\
ORC-NPP6-1A & ORCHIDEE-FM modified & WCLIMCRU & ESDB v2.0 \\
LPJ-1A & LPJ-wsl & WCLIMCRU & ESDB v2.0 \\
LPJ-1B & LPJ-wsl & CRU TS 3.0 & $1.5 \mathrm{~m}$ \\
LPJ-3A & LPJ-wsl & CRU TS 3.0 & ESDB v2.0 \\
LPJ-3B & LPJ-wsl & & $1.5 \mathrm{~m}$
\end{tabular}

ORCHIDEE-FM and ORCHIDEE-STD respectively represent the version of ORCHIDEE with and without forest management, which explicitly modeling forest stand growth and management.

\section{LPJ-wsl}

LPJ-wsl calculates photosynthesis on a daily basis following the Farquhar and others (1980) bio- chemical model coupled to soil moisture stress via the Haxeltine and Prentice (1996) formulation for stomatal conductance. NPP is estimated as the dif- 
(a)
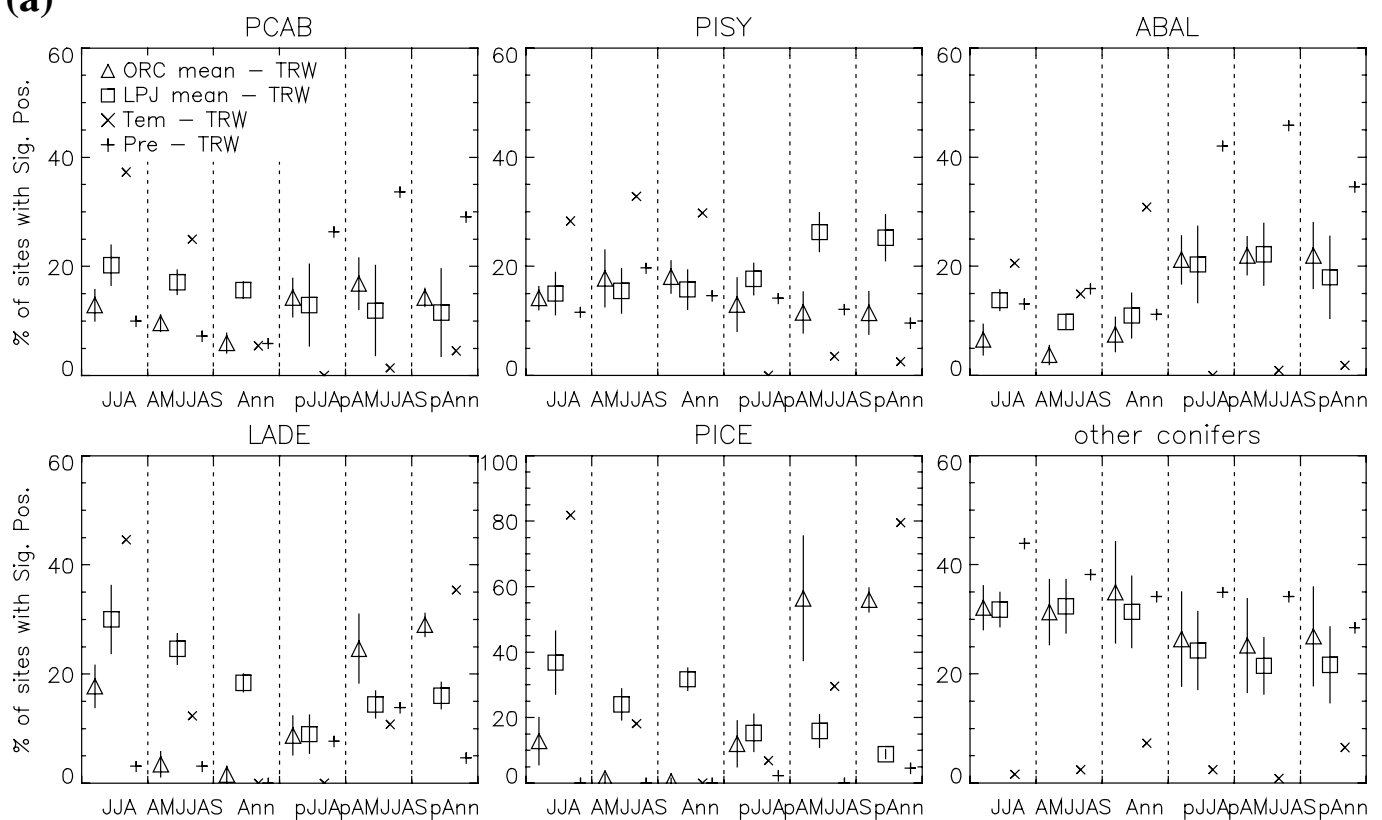
PICE other conifers
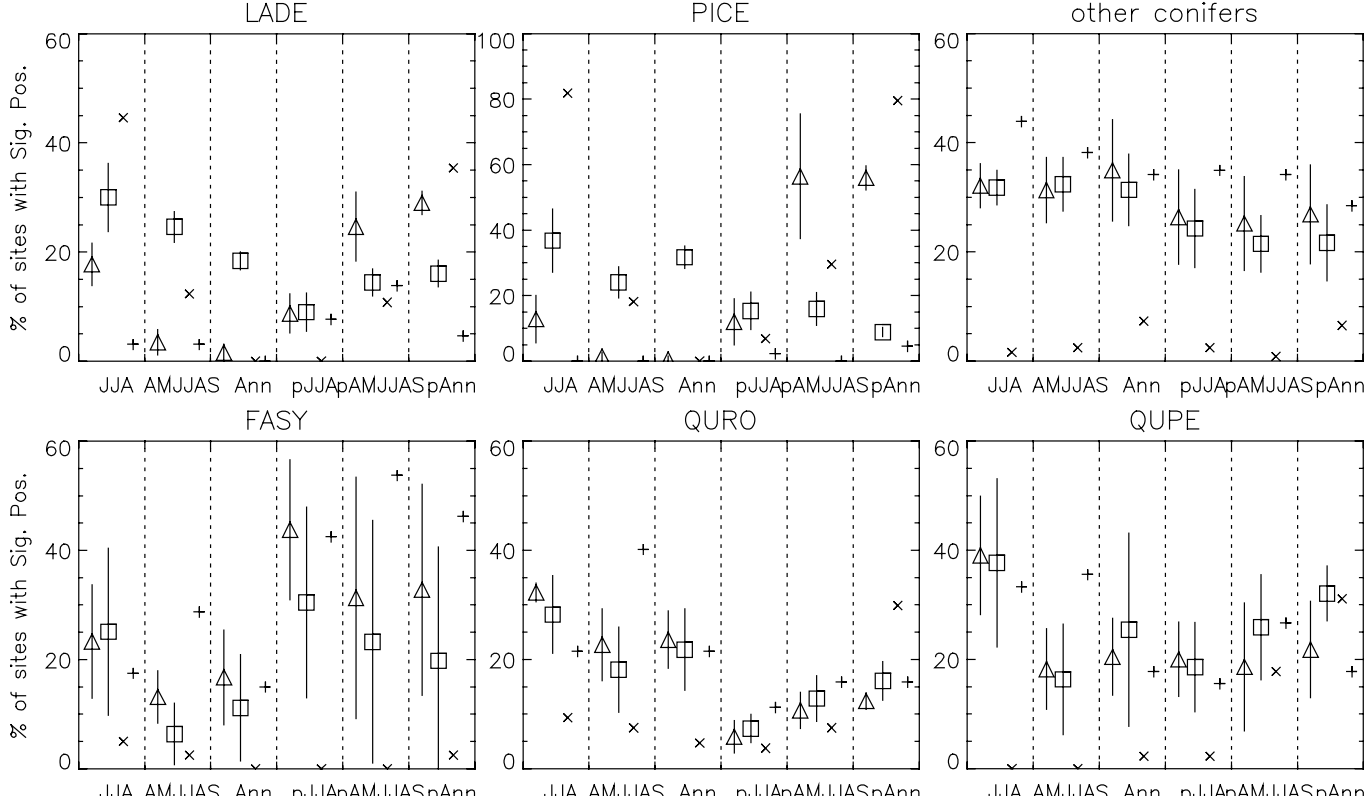

JJA AMJJAS Ann pJJApAMJJASpAnn

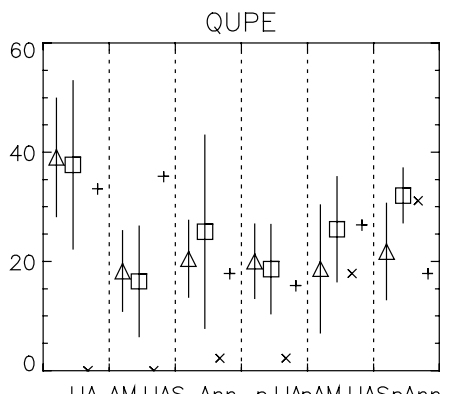

(b)
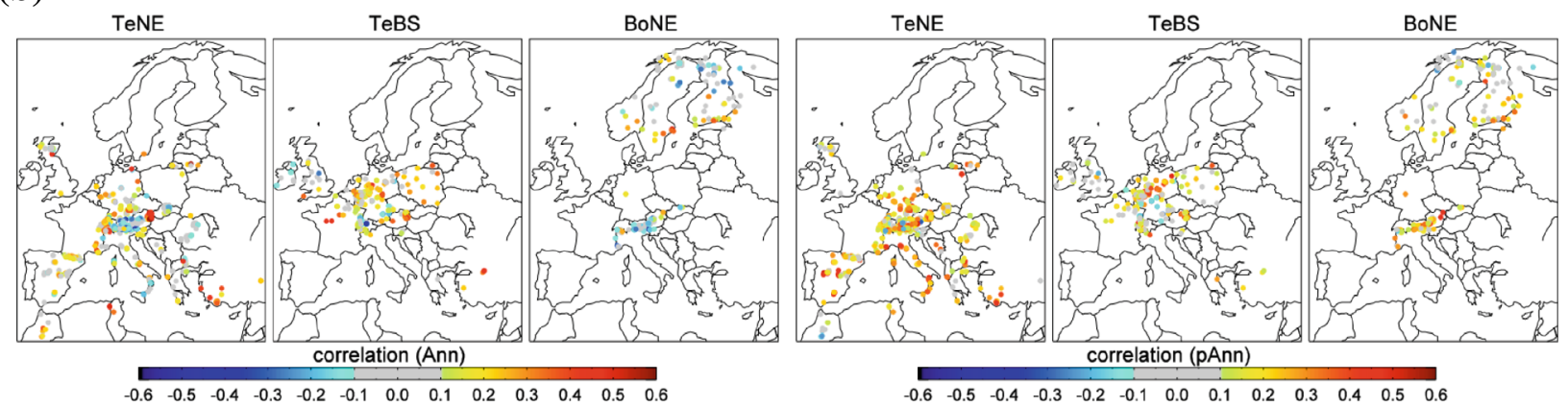

(c)
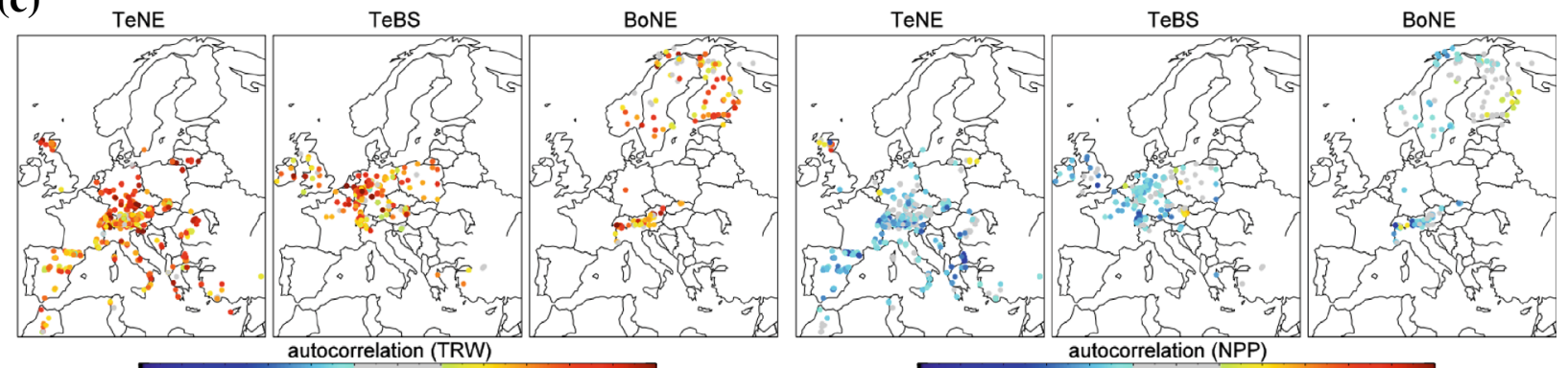
4Figure 2. Correlation coefficients between tree ring width (TRW) and simulated net primary productivity (NPP), temperature (TEM), and precipitation (PRE) of different intervals of the year during 1920-1970 (JJA: June-August; AMJJAS: April-September; Ann: whole year; pJJA, pAMJJAS, and pAnn stand for the corresponding intervals of the year prior to growth). A Mean $( \pm 1 \mathrm{SD}$, error bar) percentage of sites per species with significant $(p=0.05)$ positive correlations. B Spatial distributions of correlation coefficients between TRW and ORC-FM-1A (see Table 1) simulated NPP in Ann and pAnn; C spatial distributions of auto-correlation coefficients of TRW between Ann and pAnn, and the same for ORC-FM-1A simulated annual NPP.

ference between GPP minus reproductive cost ( $10 \%$ of the allocatable assimilates), growth respiration $(25 \%$ of the allocatable assimilates), and maintenance respiration (Collatz and others 1991). Simulations (without fire) were conducted limiting the establishment of PFTs to site-specific phenology types. The standard runs used soil depth and texture also from FAO (Zobler 1986), using a twolayer bucket model with a total soil depth of $1.5 \mathrm{~m}$.

\section{Meteorological Data}

Three gridded meteorology products were used as forcing data for the two vegetation models: CRU TS 3.0 with $0.5^{\circ}$ spatial resolution and monthly time step; WCLIMCRU with downscaled $1 \mathrm{~km}$ spatial resolution and monthly time step; and CRUNCEP with $0.5^{\circ} \times 0.5^{\circ}$ spatial resolution and 6 hourly time step. These data products are available for the 1901-2005 period.

\section{CRU TS 3.0}

The CRU TS 3.0 data are monthly gridded fields produced by the Climatic Research Unit (CRU) at the University of East Anglia (Harris and others 2014). The climate data that we used for model simulations includes monthly temperature, precipitation, wet days, and cloud cover.

\section{WCLIMCRU}

WCLIMCRU combines the temporal variability from CRU TS 3.0 (Mitchell and Jones 2005) with the fine-spatial resolution topography from WorldClim (Hijmans and others 2005) by spatially downscaling the corresponding climatologies to include finer-scale altitudinal data and the associated effects on mean climate. This was particularly important in our study because many of the tree ring chronology locations are in mountainous re- gions where small horizontal distances are associated with large changes in elevation. A monthly temperature and precipitation climatology was calculated from CRU TS 3.0 for the base periods 1950-2000 that corresponded to the WorldClim climatology. First, monthly temperature anomalies were calculated by subtracting the long-term monthly means from the entire CRU TS 3.0 time series (1901-2005); relative precipitation anomalies were calculated by dividing observed precipitation by monthly means. Then the anomalies were bi-linearly interpolated to $1 \mathrm{~km}$ resolution and added (or multiplied in the case of precipitation) to the WorldClim $1 \mathrm{~km}$ resolution climatology.

\section{CRUNCEP}

CRUNCEP is a multi-year climate forcing data product including air temperature, precipitation, shortwave radiation, long wave radiation, air specific humidity, wind speed, and atmospheric pressure, with a 6 -h time step and $0.5^{\circ}$ spatial resolution (http://dods.extra.cea.fr/data/p529viov/ cruncep/). This forcing dataset is a combination of two existing climate datasets: the CRU TS.2.1 0.5 monthly climatology covering the periods 19012005 (http://www.cru.uea.ac.uk/ timm/grid/ CRU_TS_2_l.html) and the NCEP reanalysis data at $2.5^{\circ}$ spatial resolution and 6-h time step beginning in 1948 and available in near real time (http:// www.ncdc.noaa.gov/oa/climate/climatedata.html). The NCEP data are first interpolated spatially to the CRU grid with $0.5^{\circ}$ resolution. Then CRUNCEP forcing ( $\mathrm{cn}$; 6-hourly) is calculated as: $\mathrm{cn}=\mathrm{Cl}$ $N \times n$, except for temperature as: $\mathrm{cn}=n+(C-N)$, where $C$ is the CRU monthly value (capitals $=$ monthly), $n$ is the NCEP 6-hourly, and $N$ the NCEP monthly value. Prior to 1948 when NCEP starts, we used the same procedure but applied 6hourly variability of NCEP data from the year 1948 to each year instead.

\section{Soil Depth}

In addition to the standard, or default, soil depths of 2 (ORCHIDEE) and $1.5 \mathrm{~m}$ (LPJ-wsl) for all sites, we used site-specific soil depth data from the ESDB v2.0 (European Soil DataBase)—l km Raster Library provided by JRC (Joint Research Centre of the European Commission) for model simulations. The variable 'depth to rock' was selected to represent total soil depth where roots are able to access water. Plant available water was estimated as the difference between soil water content at field capacity and wilting point and adjusted by soil depth. 


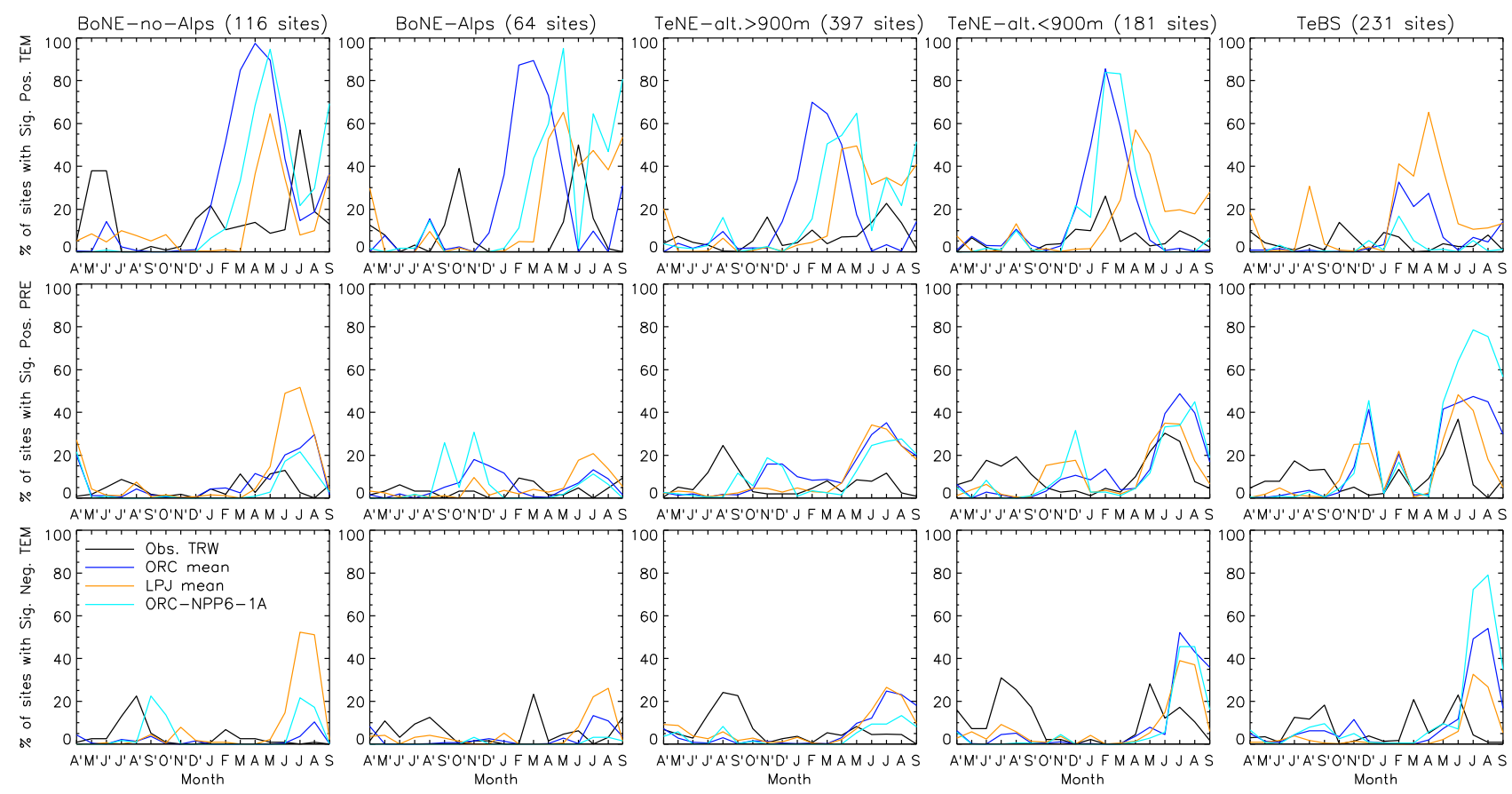

Figure 3. Percentage of sites per PFTs with significant (Sig., $p=0.05$ ) positive (Pos.) and negative (Neg.) correlations between tree ring width (TRW)/simulated annual NPP and monthly temperature (TEM)/precipitation (PRE) from April lst of the previous year $\left(\mathrm{A}^{\prime}\right)$ to September 30th of the current year (S) during 1920-1970. "BoNE-no-Alps" and "BoNE-Alps" represents boreal needleleaf evergreen (BoNE) sites not distributed in Alps region and in Alps region respectively, whereas

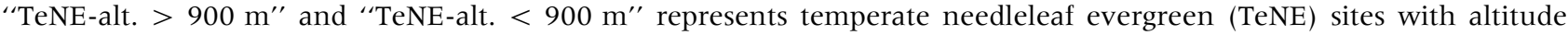
above $900 \mathrm{~m}$ and below $900 \mathrm{~m}$ respectively.

\section{Model Simulations}

Based on the three different climate forcing datasets (WCLIMCRU, CRUNCEP, and CRU TS 3.0) and the two possible soil parameterization schemes, that is, the model prescribed default depth value, and the ESDB v2.0 depth, we developed ten scenarios for ORCHIDEE and LPJ-wsl as follows; ORCNPP6 $(n=1)$, ORCHIDEE-FM $(n=4)$, ORCHIDEESTD $(n=1)$, and LPJ-wsl $(n=4)$ at each site of the tree ring network during 1901-2005 (Table 1). A 1000 -year spin-up using the first 30 years of climate data and pre-industrial $\mathrm{CO}_{2}$ concentration of $286 \mathrm{ppm}$, was used to bring the energy, carbon and hydrology budgets into equilibrium for ORCHIDEE and LPJ-wsl, followed by the transient simulation with observed climate forcing datasets and $\mathrm{CO}_{2}$ from Keeling and Whorf (2005).

\section{Data Detrending and Analyses}

Before comparing simulated NPP and observed TRW, and analyzing their response to climate variability, we detrended all datasets to eliminate biological age effects and other factors that may confound the climate signals. To remove these unwanted longer-term trends from the measured TRW series, simulated NPP, and climate datasets at each site, we divided their raw values by a cubic smoothing spline basis with a $50 \%$ frequency cutoff threshold of 10 years. This procedure retained only the inter-annual to decadal variability in the resulting dimensionless indices.

Correlation analyses between detrended NPP and TRW were performed for each site over the 19201970 period. For this purpose, we averaged NPP over different seasons, including seasons of the year prior to ring formation, before calculating Pearson's correlation coefficients between seasonal NPP and TRW indices. Monthly and seasonal climate data, including months of the year prior to ring formation, were also used for correlation analyses with TRW and NPP indices.

In addition, we calculated the temperature sensitivity of simulated NPP at each site as the slope of a simple linear regression between detrended early (March-May, MAM) and core growing season (April-Sep, AMJJAS) temperature and detrended annual NPP. The same temperature sensitivity was calculated for TRW indices during the 1920-1970 periods as a reference. 

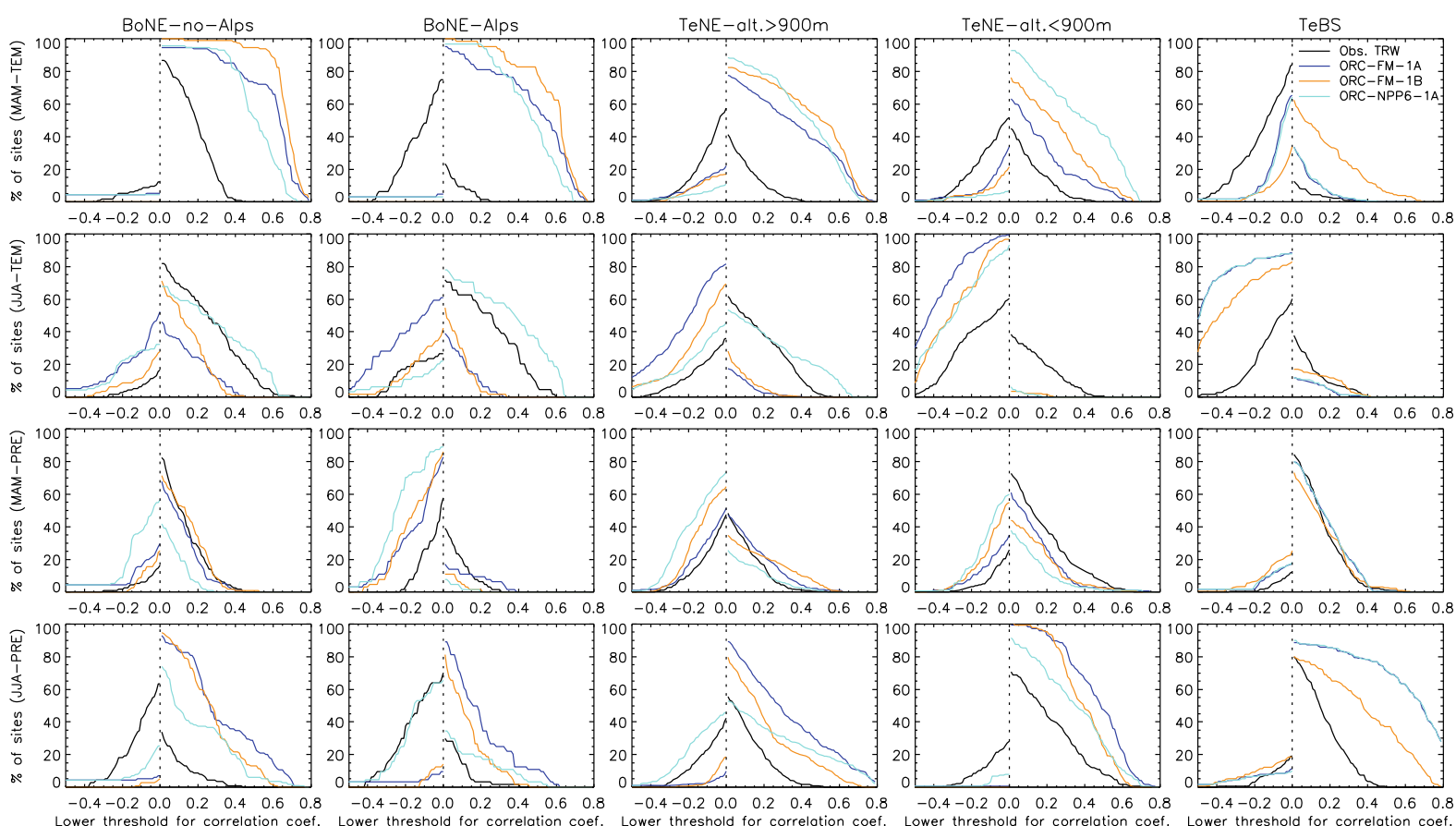

Figure 4. Percentage of sites per plant functional type (PFT) in which tree ring width (TRW) and simulated annual net primary productivity (NPP) are controlled by spring (March-May, MAM) and summer (June-August, JJA) temperature (TEM) and precipitation (PRE) during 1920-1970, depending on the chosen threshold for their Pearson's correlation coefficients.

\section{RESULTS}

\section{Correlation Between Simulated NPP and Observed TRW Variability}

Across all species and assessed seasons, 18 and $21 \%$ of the correlations were significant between TRW and simulated NPP from ORCHIDEE-FM version and LPJ-wsl, respectively. Generally, both models performed similarly in these assessments. The most relevant seasons for summing NPP, as identified by the percentage of sites with positive correlations with TRW, were current year summer and growing season NPP. Abies alba and Fagus sylvatica sites that are mainly found in central Europe show more significant positive correlations with previous year NPP $(\sim 20-40 \%)$ both in ORCHIDEE and LPJ-wsl (Figure 2A). Such lagged relationships between TRW and NPP from ORCHIDEE are especially noticeable for many conifer species sites in the Alps, with approximately $30 \%$ of Larix decidua and approximately $60 \%$ of Pinus cembra sites showing significant positive correlations of TRW with previous year annual NPP (Figure 2A). Unlike conifer species, the majority of broadleaf sites show a higher correlation between TRW and NPP of current year (Figure 2B). Nearly half of the needleleaf sites in the Alps and about 15\% of boreal needleleaf sites from Scandinavia exhibit negative correlations between TRW and current year NPP (Figure 2B). One possible explanation is that the strong lagged effects of past climate on current TRW (so-called "biological memory") are not well represented in DGVMs. This is compounded by the strong positive correlation between TRW and previous year's temperature or precipitation for the major conifer species (Figure 2A). Accordingly, such factors lead to pronounced differences in the auto-correlation structures of TRW compared to NPP (Figure 2C).

\section{TRW and NPP Sensitivities to Monthly Climate}

Generally, annual NPP showed higher correlations with temperature than the observed TRW for both conifers and broadleaved species. NPP also showed strong lagged responses to climate (Figure 3). In addition, TRW showed a much stronger relationship with previous year climate than modelled NPP for both temperature and precipitation. Many conifer sites show a significant positive TRW response to current-year summer temperature $\left(T_{\mathrm{JJA}}\right.$, $\sim 50 \%$ of BoNE), to previous-year spring temperature ( $T_{\mathrm{MAM}}, \sim 40 \%$ of BoNE outside the Alps), and 

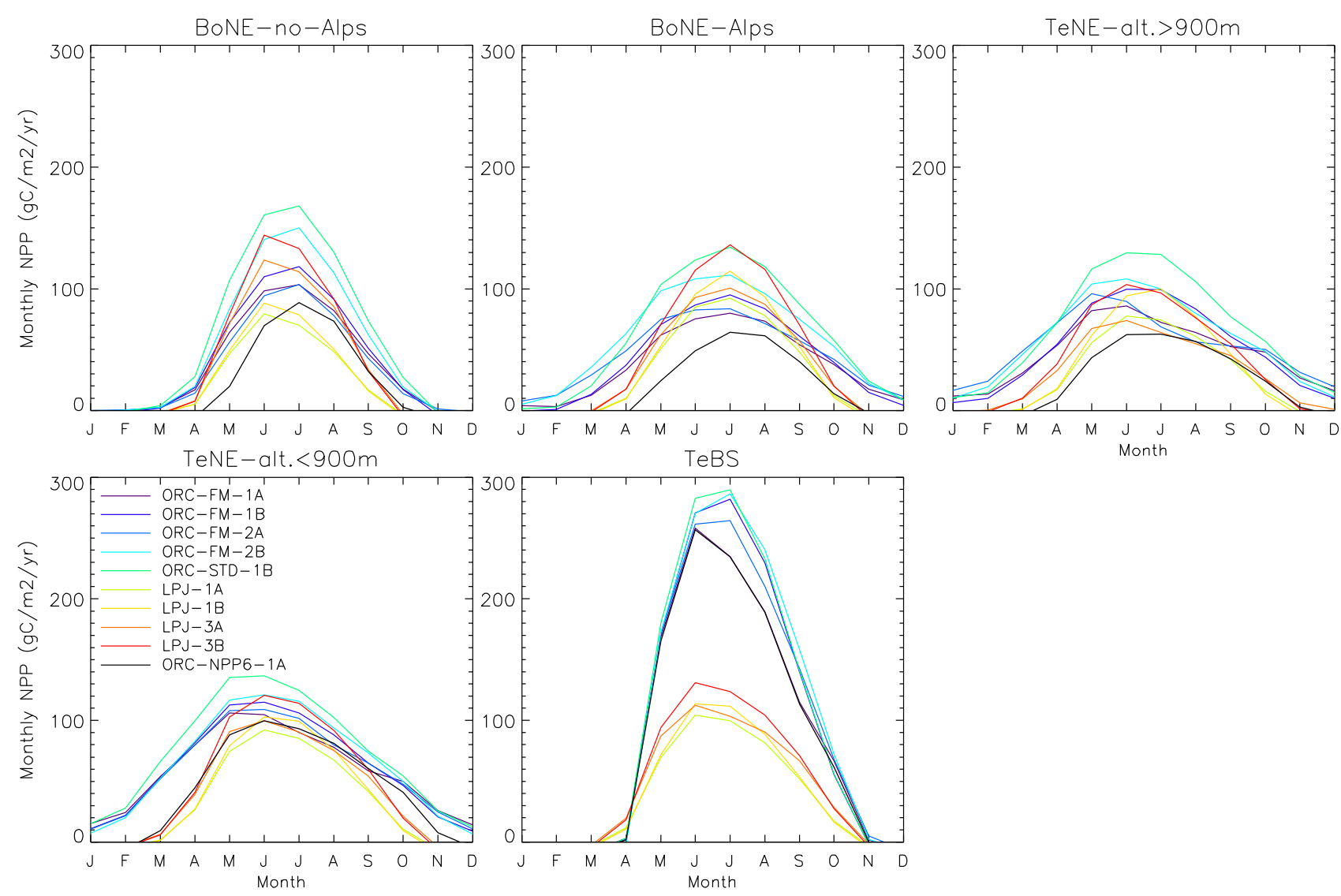

Figure 5. Mean monthly NPP from models for the PFTs during 1920-1970.

to current-year summer precipitation $\left(P_{\mathrm{JJA}}, \sim 30 \%\right.$ of low-altitude TeNE). The TRW at many broadleaf sites responds significantly positively to previousyear summer precipitation $\left(P_{\mathrm{JJA}}, \sim 20 \%\right.$ of TeBS) and current-year $P_{\mathrm{JJA}}(\sim 40 \%$ of TeBS). Lastly, NPP correlations with temperature tend to peak earlier in the current year compared to the correlations between temperature and TRW. The highest significant positive temperature response of annual NPP (especially from ORCHIDEE) at BoNE and TeNE sites above $900 \mathrm{~m}$ occurs in spring, whereas TRW response is strongest in summer at these sites. The conifer TeNE sites below $900 \mathrm{~m}$ do not show this different seasonality in ORCHIDEE, suggesting a larger structural bias of ORCHIDEE for coniferous forests in cold boreal and mountain regions compared with temperate regions.

ORC-NPP6 shows better seasonal agreement with the climate response observed from TRW among all model runs. The highest significant positive response of NPP in ORC-NPP6 to monthly temperature is shifted from spring to the summer months, and is thus in better agreement with the
TRW response. This improvement results from the modifications made in ORC-NPP6 that were designed to limit the response of NPP to spring temperature. For broadleaf species, the significant positive response of NPP to temperature in ORCNPP6 also substantially improved, despite the fact that this version seems to yield too strong (positive) responses of NPP to summer precipitation and too weak (negative) responses to summer temperature. There are also obvious distinctions between ORCHIDEE and LPJ-wsl NPP responses to temperature, particularly for conifer species. The highest significant positive response of ORCHIDEE NPP to temperature is greater and occurs one to two months earlier than the response of LPJ-wsl.

\section{TRW and NPP Sensitivities to Interannual Climate Variability During the Growing Season}

For most sites, both ORCHIDEE and LPJ-wsl overestimate the positive sensitivities of woody NPP to $T_{\mathrm{MAM}}$ and $P_{\mathrm{JJA}}$, and conversely underestimate neg- 


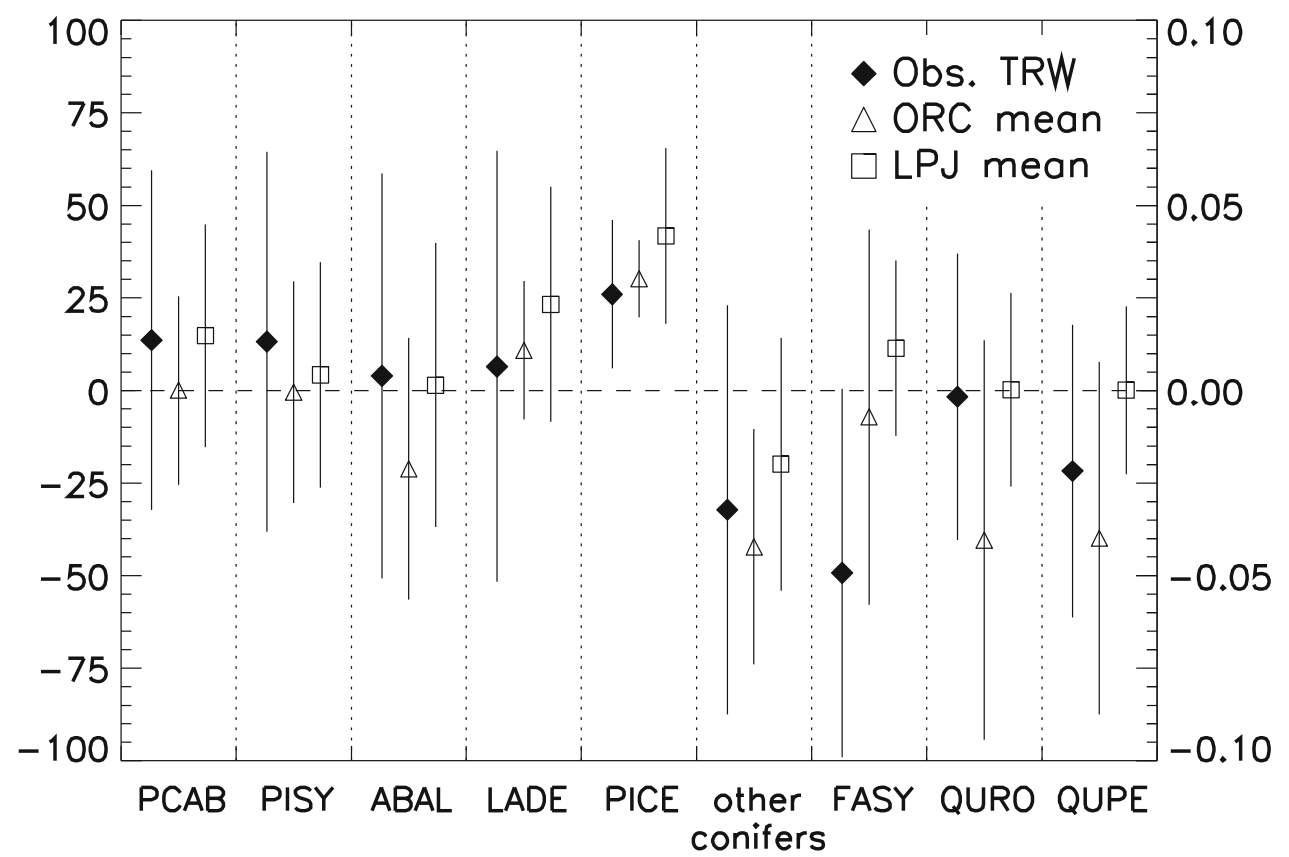

Figure 6. Temporal temperature sensitivity of simulated annual NPP ( $\mathrm{gC}$ $\mathrm{m}^{-2} \mathrm{y}^{-1}$ per ${ }^{\circ} \mathrm{C}$ ) and observed TRW indices to growing season temperature (AprilSeptember) for the species groups during 1920-1970. Error bars represents one standard deviation.

ative sensitivities for the same seasons (Figure 4). Accordingly, the fraction of sites that are more positively correlated with $T_{\text {MAM }}$ is much higher for NPP than for TRW for all PFTs. TRW at approximately $20 \%$ of the BoNE sites exhibits a significant negative response to $\mathrm{T}_{\text {MAM }}(n=50, R>0.27, p=0.05)$, whereas annual NPP does not show this response. The correlations of annual NPP to $T_{\mathrm{JJA}}$ and $P_{\mathrm{MAM}}$ is in better agreement with the TRW observations, except that NPP at $20 \%$ of the low-altitude TeNE sites and approximately $60 \%$ of the TeBS sites is significantly negatively correlated to $T_{\text {JJA }}$ while TRW is not. For all species, NPP tends to be more strongly correlated with $P_{\text {JJA }}$ than the TRW observations. The spatial distributions of sites with a significant positive response $(n=50, R>0.27, p=0.05)$ of NPP and TRW to precipitation and temperature in growing season is generally comparable, but with discrepancies for $T_{\text {MAM }}$ in Scandinavia and the Alps and $P_{\mathrm{JJA}}$ in Central Europe.

Different parameterization schemes used in the model runs introduced variability in the NPP correlations with climate, either through soil depth schemes that influence soil moisture availability in summer, or through parameter calibration of temperature thresholds that control the onset of NPP (Figure 4). Soil depths derived from ESDB v2.0 are almost always less than $1 \mathrm{~m}$ and never over $1.5 \mathrm{~m}$, thus more shallow than the default value used in the models. This leads to increased water stress in the simulations during dry summers. As such, in the ORCHIDEE simulations with the ESDB v2.0 soil depth (ORC-FM-1A), NPP exhibits a less positive correlation to $T_{\mathrm{MAM}}$, a more positive correlation to $P_{\mathrm{JJA}}$, and a more negative correlation to $T_{\mathrm{JJA}}$ than in the run prescribed with a uniform two-meter soil depth (ORC-FM-1B). However the spatial pattern and inter-species variability remains the same regardless of soil depth. For the parameter controlling forest growth threshold, it shows that calibration of onset temperature will improve ORCHIDEE model performance for BoNE sites and high-latitude TeNE sites. The correlations of NPP in ORC-NPP6-1A with $T_{\mathrm{JJA}}$ and $P_{\mathrm{JJA}}$ are more comparable with the TRW observations at the 'cold conifer' BoNE sites and the high-altitude TeNE sites. However, there is an overestimation of correlation between NPP and $P_{\mathrm{JJA}}$ at TeBS sites, indicating that finer parameterization for representing phenology need to be accounted in DGVMs.

\section{Discussion}

\section{Benchmarking DGVMs with TRW}

Applying tree-ring parameters as benchmarks for vegetation models provides novel insight in the responses of terrestrial ecosystems to environmental variation and extremes (Babst and others 2014b) and at the same time highlights promising avenues for future model development to reduce existing uncertainties (Girardin and others 2014). The two ecosystem models used herein were general able to reproduce the responses of tree growth to climate for the most abundant species in Europe. Yet, there are three main sources of model-data 

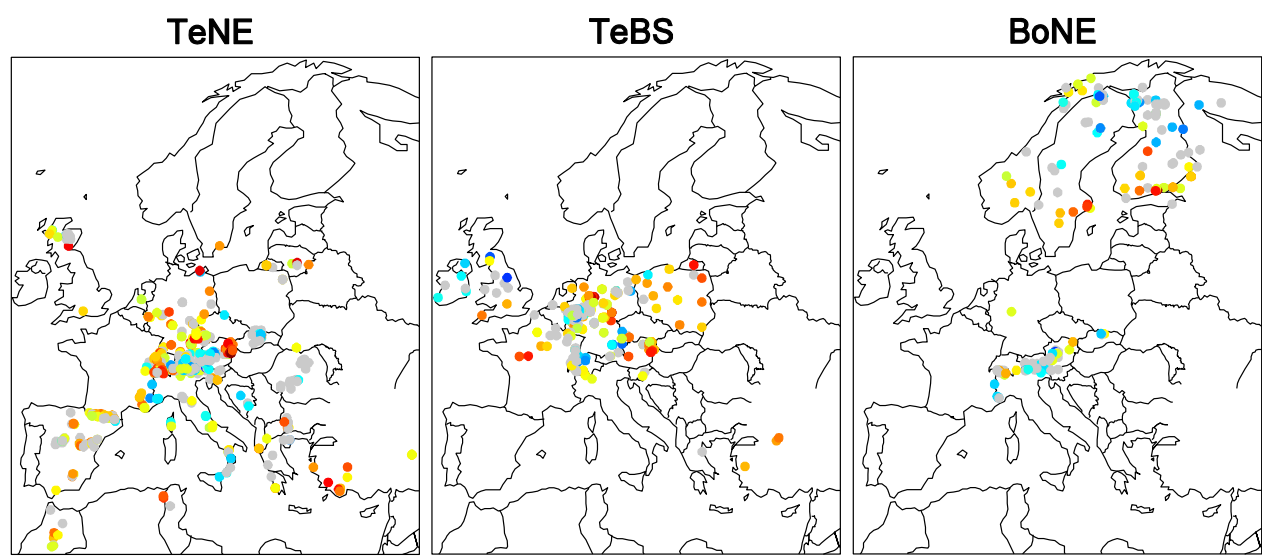

Figure 7. Spatial

distributions of correlation coefficients between TRW and ORCFM-1 A simulated annual NPP during the 19201970 periods which exclude the years whose anomaly of spring (March-May, MAM) or summer (June-August, JJA) temperature (TEM) or precipitation (PRE) is out of \pm 2 SD range.

\section{correlation (Ann)}

$\begin{array}{lllllllllllll}-0.6 & -0.5 & -0.4 & -0.3 & -0.2 & -0.1 & 0.0 & 0.1 & 0.2 & 0.3 & 0.4 & 0.5 & 0.6\end{array}$

differences that emerged in both in ORCHIDEE and LPJ-wsl in simulating (1) growth phenology, (2) sensitivity to climatic drivers, and (3) lagged effects. The weak correlations between observed TRW and simulated NPP that we found for BoNE sites and high-altitude TeNE sites are likely due to (1) and (2), whereas and those for low-altitude TeNE sites and TeBS sites are mainly due to (2) and (3). A phenology simulation bias of process-based ecosystem models was reported by Richardson and others (2012), and was somewhat mitigated in our ORC-NPP6 run by modifying temperature thresholds in the phenology module.

Between-model differences in the responses of ORCHIDEE and LPJ-wsl NPP to temperature for conifers are most likely due to divergent simulation of phenology. Large differences in winter and early spring NPP emerged between the models, with ORCHIDEE having longer seasons with positive NPP (Figure 5). After the modifications of the NPPonset temperature threshold, ORC-NPP6 NPP shows a more similar temperature response to LPJwsl than the original ORCHIDEE NPP (Figure 3). For broadleaved species, similar seasonal patterns in NPP were simulated by ORCHIDEE and LPJ-wsl, but peak annual NPP in ORCHIDEE is about twice larger than in LPJ-wsl (Figure 5). Similarly, ORCHIDEE and LPJ-wsl NPP exhibits comparable responses to temperature for broadleaved species, but with different magnitudes.

The higher temperature threshold for growth that we implemented in ORC-NPP6 partly mitigated the drawback due to the lack of a soil-freezing module in ORCHIDEE and LPJ-wsl. The different climate response of both models compared to TRW data is in line with conclusions drawn from a previous assessment of model and eddy-covariance data by Beer and others (2010). They reported a similar tendency in 5 process-based models to overestimate the sensitivity of gross primary productivity (GPP) to precipitation gradients across the globe. Climatic sensitivity may stem from the implementation of combined effect of temperature and precipitation on maximum carboxylation rates $\left(V_{\mathcal{c}_{\max }}\right)$ in the models in cool regions and dry regions, which represent forest dependence on water stress. This calls for a better understanding of how photosynthesis model parameters vary with PFTs and climate and as well as for long-term and spatially extensive data of these plant traits to improve model performance (Piao and others 2013).

\section{TRW and NPP Responses to Climate Extremes}

Numerous studies have highlighted the important ecological consequences of extreme heatwaves and droughts, including increased forest mortality and growth reductions in subsequent years (Ciais and others 2005; Anderegg and others 2015). Even in humid forests, growth and mortality are highly sensitive to drought (Nepstad and others 2007). Our results show spatially coherent declines in both TRW and NPP when extreme droughts and high temperature occurred across a particular region. Due to the lack of lagged effects for both ORCHIDEE and LPJ-wsl, no obvious NPP reductions occurred in the years following the 1959 and 1976 extreme weather episodes. According to IPCC (2013), projected increases in air temperature are associated with increases in mean annual precipitation in northern Europe, but reduced precipitation for more southerly latitudes. Rising temperatures, with associated enhanced atmospheric evaporative demand, can lead to drought stress, especially in the Mediterranean and conti- 
nental temperate regions (Jacob and others 2014). These projections suggest that forests around Mediterranean regions are at risk of strongly increasing water stress and consequently declining productivity in future. On the other hand, the increases in temperature coupled with precipitation are beneficial for boreal forests and temperate forests at high elevations where water is less of a limiting factor (Keyan and others 2015). This suggests a strong need of more realistic representations of interactions between large-scale climate extremes and terrestrial productivity in land surface models.

\section{NPP Sensitivity to Monthly Climate in DGVMs and their Lag Effect}

At continental to global scales, Friedlingstein and others (2013) reported a negative sensitivity of land and marine carbon storage to future climate change in 11 coupled global carbon-cycle climate models. By inferring the temperature sensitivity of TRW and NPP for different species, we found that boreal conifer species positively respond to temperature, whereas Mediterranean conifers and temperate broadleaves are not. These species-specific differences in climate response are also related to their distributions in bioclimatic space (Figure 6). The strong positive temperature sensitivity of NPP of conifers in northern Europe and the Alps is in agreement with the results of Wieser and others (2009), who projected that GPP of timberline forests in the Alps rises by approximately 15\% per $1.0^{\circ} \mathrm{C}$ warming. In boreal regions, we find a gradual increase in annual NPP simulated by ORCHIDEE throughout the last century for the major conifer species, implying an enhanced positive effect of rising temperature on NPP as suggested by satellite observations (Zhao and Running 2010). On the other hand, broadleaf species and conifers in the Mediterranean regions exhibit strong responses to precipitation with a near zero or negative response to temperature of TRW and NPP. However, for these broadleaf and conifers sites, large differences exist between the annual NPP simulated by ORCHIDEE and annual NPP simulated by LPJ-wsl. Again, discrepancies between the model structures appear to render ORCHIDEE more sensitive to precipitation and soil moisture than LPJ-wsl.

The lagged response to previous-year summer precipitation and temperature in the TRW observations for TeNE and TeBS sites was also demonstrated in a recent study (Babst and others 2013). To test whether such lagged effects that seldom appear in modeled NPP are mainly from climate extremes, we calculated correlations between TRW and NPP only for the years that did not follow a particularly dry or hot year (Figure 7). These selective correlations did not improve compared with the correlations from the whole period, implying lagged climatic effects on TRW as a common occurrence in normal years as well. These results, along with the high auto-correlation that is commonly found in TRW observations but seldom in NPP simulations, indicate that the models lack biological processes and lagged effects that govern radial tree growth (Gessler and others 2014). Such missing carry over processes in the models stems from the lack of appropriate carbohydrate reserves for evergreen conifers, and very small carbohydrate reserves for deciduous PFTs kept from the previous year. This could for example be addressed by adjusting the existing, or by adding a more sophisticated plant carbohydrate reserve pool (Fatichi and others 2014) in DGVMs to control carbohydrate remobilization for leaf production and the growth of other plant organs in the following year.

\section{ConCLUSION}

This study provides a detailed assessment of observed and modeled forest responses to climate variability across Europe. In both the NPP simulations and TRW network, species located in northern Europe and the Alps are more sensitive to spring and summer temperature than the species located in central Europe and Mediterranean regions that are regularly limited by soil moisture. For the conifer species that are mainly located in cold regions, temperature sensitivities of NPP simulated by ORCHIDEE increase throughout the twentieth century. NPP in both ORCHIDEE and LPJ-wsl are overly sensitive to climatic factors compared to TRW and lack the lagged effects and autocorrelation structure that are typically found in the empirical data. ORCHIDEE and LPJ-wsl NPP disagree on the response to temperature at many conifer sites, possibly because of divergent treatment of phenology parameterizations and feedbacks on GPP/NPP onset of the models. By introducing subtle modifications to ORCHIDEE growing season temperature thresholds in the ORC-NPP6 run, we were able to mitigate some of these biases. Our results show spatially coherent declines in both TRW and modeled NPP when extreme droughts and high temperature occurred across a particular region. Our study demonstrates that tree-ring data are a useful source of annually resolved information on forest growth and climate 
response that can be used to benchmark and inform global vegetation models and thus contribute to refined predictions of the fate of the terrestrial biosphere.

\section{ACKNOWLEDGEMENTS}

This work was funded by the European Commission FP7 Project CARBO-Extreme (FP7-ENV-20081-226701). ZZ acknowledges funding by the CCES MAIOLICA project \#42-01 and the National Natural Science Foundation of China (Y411391001). FB acknowledges funding from the EU Horizon-2020 project "BACI" (Grant 640176) and the Swiss National Science Foundation (Grant P300P2_154543). We thank all tree-ring data collectors for sharing their data on the International Tree-Ring Data Bank.

\section{REFERENCES}

Anderegg WRL, Schwalm C, Biondi F, Camarero JJ, Koch G, Litvak M, Ogle K, Shaw JD, Shevliakova E, Williams AP, Wolf A, Ziaco E, Pacala S. 2015. Pervasive drought legacies in forest ecosystems and their implications for carbon cycle models. Science 349:528-32.

Babst F, Alexander MR, Szejner P, Bouriaud O, Klesse S, Roden J, Ciais P, Poulter B, Frank D, Moore DP, Trouet V. 2014a. A tree-ring perspective on the terrestrial carbon cycle. Oecologia 176:307-22.

Babst F, Bouriaud O, Alexander R, Trouet V, Frank D. 2014b. Toward consistent measurements of carbon accumulation: a multi-site assessment of biomass and basal area increment across Europe. Dendrochronologia 32:153-61.

Babst F, Poulter B, Trouet V, Tan K, Neuwirth B, Wilson R, Carrer M, Grabner M, Tegel W, Levanic T, Panayotov M, Urbinati C, Bouriaud O, Ciais P, Frank D. 2013. Site- and species-specific responses of forest growth to climate across the European continent. Glob Ecol Biogeogr 22:706-17.

Ball JT, Woodrow I, Berry J. 1987. A model predicting stomatal conductance and its contribution to the control of photosynthesis under different environmental conditions. In: Biggins J, Ed. Progress in photosynthesis research. Netherlands: Springer. pp 221-4.

Beer C, Reichstein M, Tomelleri E, Ciais P, Jung M, Carvalhais N, Rödenbeck C, Arain MA, Baldocchi D, Bonan GB, Bondeau A, Cescatti A, Lasslop G, Lindroth A, Lomas M, Luyssaert S, Margolis H, Oleson KW, Roupsard O, Veenendaal E, Viovy N, Williams C, Woodward FI, Papale D. 2010. Terrestrial gross carbon dioxide uptake: global distribution and Covariation with climate. Science 329:834-8.

Bellassen V, Le Maire G, Dhôte JF, Ciais P, Viovy N. 2010. Modelling forest management within a global vegetation model-part 1: model structure and general behaviour. Ecol Model 221:2458-74.

Bellassen V, Viovy N, Luyssaert S, Le Maire G, Schelhaas M-J, Ciais P. 2011. Reconstruction and attribution of the carbon sink of European forests between 1950 and 2000. Glob Chang Biol 17:3274-92.

Berninger F, Hari P, Nikinmaa E, Lindholm M, Meriläinen J. 2004. Use of modeled photosynthesis and decomposition to describe tree growth at the northern tree line. Tree Physiol 24:193-204.

Breitenmoser P, Brönnimann S, Frank D. 2014. Forward modelling of tree-ring width and comparison with a global network of tree-ring chronologies. Clim Past 10:437-49.

Charney ND, Babst F, Poulter B, Record S, Trouet VM, Frank D, Enquist BJ, Evans MEK. 2016. Observed forest sensitivity to climate implies large changes in 21 st century North American forest growth. Ecol Lett 19:1119-28.

Ciais P, Reichstein M, Viovy N, Granier A, Ogee J, Allard V, Aubinet M, Buchmann N, Bernhofer C, Carrara A, Chevallier F, De Noblet N, Friend AD, Friedlingstein P, Grunwald T, Heinesch B, Keronen P, Knohl A, Krinner G, Loustau D, Manca G, Matteucci G, Miglietta F, Ourcival JM, Papale D, Pilegaard K, Rambal S, Seufert G, Soussana JF, Sanz MJ, Schulze ED, Vesala T, Valentini R. 2005. Europe-wide reduction in primary productivity caused by the heat and drought in 2003. Nature 437:529-33.

Collatz GJ, Ball JT, Grivet C, Berry JA. 1991. Physiological and environmental regulation of stomatal conductance, photosynthesis and transpiration: a model that includes a laminar boundary layer. Agric For Meteorol 54:107-36.

D'Orangeville L, Duchesne L, Houle D, Kneeshaw D, Côté B, Pederson N. 2016. Northeastern North America as a potential refugium for boreal forests in a warming climate. Science 352:1452-5.

Farquhar GD, von Caemmerer S, Berry JA. 1980. A biochemical model of photosynthetic $\mathrm{CO}_{2}$ assimilation in leaves of $\mathrm{C} 3$ species. Planta 149:78-90.

Fatichi S, Leuzinger S, Körner C. 2014. Moving beyond photosynthesis: from carbon source to sink-driven vegetation modeling. New Phytol 201:1086-95.

Frank DC, Poulter B, Saurer M, Esper J, Huntingford C, Helle G, Treydte K, Zimmermann NE, Schleser GH, Ahlstrom A, Ciais P, Friedlingstein P, Levis S, Lomas M, Sitch S, Viovy N, Andreu-Hayles L, Bednarz Z, Berninger F, Boettger $T$, D`Alessandro CM, Daux V, Filot M, Grabner M, Gutierrez E, Haupt M, Hilasvuori E, Jungner H, Kalela-Brundin M, Krapiec M, Leuenberger M, Loader NJ, Marah H, Masson-Delmotte V, Pazdur A, Pawelczyk S, Pierre M, Planells O, Pukiene R, Reynolds-Henne CE, Rinne KT, Saracino A, Sonninen E, Stievenard M, Switsur VR, Szczepanek M, Szychowska-Krapiec E, Todaro L, Waterhouse JS, Weigl M. 2015. Water-use efficiency and transpiration across European forests during the Anthropocene. Nature Clim. Change 5: 579-83.

Friedlingstein P, Meinshausen M, Arora VK, Jones CD, Anav A, Liddicoat SK, Knutti R. 2013. Uncertainties in CMIP5 climate projections due to carbon cycle feedbacks. J Clim 27:511-26.

Gessler A, Ferrio JP, Hommel R, Treydte K, Werner RA, Monson RK. 2014. Stable isotopes in tree rings: towards a mechanistic understanding of isotope fractionation and mixing processes from the leaves to the wood. Tree Physiol 34:796-818.

Girardin MP, Bouriaud O, Hogg EH, Kurz W, Zimmermann NE, Metsaranta JM, de Jong R, Frank DC, Esper J, Büntgen U, Guo XJ, Bhatti J. 2016. No growth stimulation of Canada's boreal forest under half-century of combined warming and $\mathrm{CO}_{2}$ fertilization. Proceedings of the National Academy of Sciences.

Girardin MP, Guo XJ, De Jong R, Kinnard C, Bernier P, Raulier F. 2014. Unusual forest growth decline in boreal North America covaries with the retreat of Arctic sea ice. Glob Chang Biol 20:851-66.

Girardin MP, Raulier F, Bernier PY, Tardif JC. 2008. Response of tree growth to a changing climate in boreal central Canada: a 
comparison of empirical, process-based, and hybrid modelling approaches. Ecol Model 213:209-28.

Harris I, Jones PD, Osborn TJ, Lister DH. 2014. Updated highresolution grids of monthly climatic observations-the CRU TS3.10 Dataset. Int J Climatol 34:623-42.

Haxeltine A, Prentice IC. 1996. BIOME3: an equilibrium terrestrial biosphere model based on ecophysiological constraints, resource availability, and competition among plant functional types. Glob Biogeochem Cycles 10:693-709.

Hijmans RJ, Cameron SE, Parra JL, Jones PG, Jarvis A. 2005. Very high resolution interpolated climate surfaces for global land areas. Int J Climatol 25:1965-78.

Hoch G, Körner C. 2009. Growth and carbon relations of tree line forming conifers at constant vs. variable low temperatures. J Ecol 97:57-66.

IPCC. 2013. Climate change 2013: the physical science basis. contribution of working group I to the fifth assessment report of the intergovernmental panel on climate change. Cambridge: Cambridge University Press. p 1535.

Jacob D, Petersen J, Eggert B, Alias A, Christensen O, Bouwer L, Braun A, Colette A, Déqué M, Georgievski G, Georgopoulou E, Gobiet A, Menut L, Nikulin G, Haensler A, Hempelmann N, Jones C, Keuler K, Kovats S, Kröner N, Kotlarski S, Kriegsmann A, Martin E, van Meijgaard E, Moseley C, Pfeifer S, Preuschmann S, Radermacher C, Radtke K, Rechid D, Rounsevell M, Samuelsson P, Somot S, Soussana J-F, Teichmann C, Valentini R, Vautard R, Weber B, Yiou P. 2014. EURO-CORDEX: new high-resolution climate change projections for European impact research. Reg Environ Chang 14:563-78.

Keeling CD, Whorf TP. 2005. Atmospheric $\mathrm{CO}_{2}$ records from sites in the SIO air sampling network. In: Trends: a compendium of data on global change. pp 16-26.

Keenan TF, Davidson E, Moffat AM, Munger W, Richardson AD. 2012. Using model-data fusion to interpret past trends, and quantify uncertainties in future projections, of terrestrial ecosystem carbon cycling. Glob Chang Biol 18:2555-69.

Keyan F, David F, Yan Z, Feifei Z, Heikki S. 2015. Moisture stress of a hydrological year on tree growth in the Tibetan Plateau and surroundings. Environ Res Lett 10:034010.

Krinner G, Viovy N, de Noblet-Ducoudré N, Ogée J, Polcher J, Friedlingstein P, Ciais P, Sitch S, Prentice IC. 2005. A dynamic global vegetation model for studies of the coupled atmospherebiosphere system. Glob Biogeochem Cycles 19: n/a-n/a.

Le Quéré C, Moriarty R, Andrew RM, Peters GP, Ciais P, Friedlingstein P, Jones SD, Sitch S, Tans P, Arneth A, Boden TA, Bopp L, Bozec Y, Canadell JG, Chini LP, Chevallier F, Cosca CE, Harris I, Hoppema M, Houghton RA, House JI, Jain AK, Johannessen T, Kato E, Keeling RF, Kitidis V, Klein Goldewijk K, Koven C, Landa CS, Landschützer P, Lenton A, Lima ID, Marland G, Mathis JT, Metzl N, Nojiri Y, Olsen A, Ono T, Peng S, Peters W, Pfeil B, Poulter B, Raupach MR, Regnier P, Rödenbeck C, Saito S, Salisbury JE, Schuster U, Schwinger J, Séférian R, Segschneider J, Steinhoff T, Stocker BD, Sutton AJ, Takahashi T, Tilbrook B, van der Werf GR, Viovy N, Wang YP, Wanninkhof R, Wiltshire A, Zeng N. 2015. Global carbon budget 2014. Earth Syst Sci Data 7:47-85.

Li G, Harrison SP, Prentice IC, Falster D. 2014. Simulation of tree-ring widths with a model for primary production, carbon allocation, and growth. Biogeosciences 11:6711-24.

Lindner M, Maroschek M, Netherer S, Kremer A, Barbati A, Garcia-Gonzalo J, Seidl R, Delzon S, Corona P, Kolström M, Lexer MJ, Marchetti M. 2010. Climate change impacts, adaptive capacity, and vulnerability of European forest ecosystems. For Ecol Manag 259:698-709.

McCree KJ. 1974. Equations for the rate of dark respiration of white clover and grain sorghum, as functions of dry weight, photosynthetic rate, and temperature. Crop Sci 14:509-14.

Misson L. 2004. MAIDEN: a model for analyzing ecosystem processes in dendroecology. Can J For Res 34:874-87.

Mitchell TD, Jones PD. 2005. An improved method of constructing a database of monthly climate observations and associated high-resolution grids. Int J Climatol 25:693-712.

Nehrbass-Ahles C, Babst F, Klesse S, Nötzli M, Bouriaud O, Neukom R, Dobbertin M, Frank D. 2014. The influence of sampling design on tree-ring-based quantification of forest growth. Glob Chang Biol 20:2867-85.

Nepstad DC, Tohver IM, Ray D, Moutinho P, Cardinot G. 2007. Mortality of large trees and lianas following experimental drought in an amazon forest. Ecology 88:2259-69.

Nippert JB, Duursma RA, Marshall JD. 2004. Seasonal variation in photosynthetic capacity of montane conifers. Funct Ecol 18:876-86

Piao S, Sitch S, Ciais P, Friedlingstein P, Peylin P, Wang X, Ahlström A, Anav A, Canadell JG, Cong N, Huntingford C, Jung M, Levis S, Levy PE, Li J, Lin X, Lomas MR, Lu M, Luo Y, Ma Y, Myneni RB, Poulter B, Sun Z, Wang T, Viovy N, Zaehle S, Zeng N. 2013. Evaluation of terrestrial carbon cycle models for their response to climate variability and to $\mathrm{CO}_{2}$ trends. Glob Chang Biol 19:2117-32.

Poulter B, Frank DC, Hodson EL, Zimmermann NE. 2011. Impacts of land cover and climate data selection on understanding terrestrial carbon dynamics and the $\mathrm{CO}_{2}$ airborne fraction. Biogeosciences 8:2027-36.

Poulter B, Hattermann F, Hawkins ED, Zaehle S, Sitch S, Restrepo-Coupe N, Heyder U, Cramer W. 2010. Robust dynamics of Amazon dieback to climate change with perturbed ecosystem model parameters. Glob Chang Biol 16:2476-95.

Rammig A, Wiedermann M, Donges JF, Babst F, von Bloh W, Frank D, Thonicke K, Mahecha MD. 2015. Coincidences of climate extremes and anomalous vegetation responses: comparing tree ring patterns to simulated productivity. Biogeosciences 12:373-85.

Richardson AD, Anderson RS, Arain MA, Barr AG, Bohrer G, Chen G, Chen JM, Ciais P, Davis KJ, Desai AR, Dietze MC, Dragoni D, Garrity SR, Gough CM, Grant R, Hollinger DY, Margolis HA, McCaughey H, Migliavacca M, Monson RK, Munger JW, Poulter B, Raczka BM, Ricciuto DM, Sahoo AK, Schaefer K, Tian H, Vargas R, Verbeeck H, Xiao J, Xue Y. 2012. Terrestrial biosphere models need better representation of vegetation phenology: results from the North American Carbon Program Site Synthesis. Glob Chang Biol 18:566-84.

Ruimy A, Dedieu G, Saugier B. 1996. TURC: a diagnostic model of continental gross primary productivity and net primary productivity. Glob Biogeochem Cycles 10:269-85.

Sitch S, Friedlingstein P, Gruber N, Jones SD, Murray-Tortarolo G, Ahlström A, Doney SC, Graven H, Heinze C, Huntingford C, Levis S, Levy PE, Lomas M, Poulter B, Viovy N, Zaehle S, Zeng N, Arneth A, Bonan G, Bopp L, Canadell JG, Chevallier F, Ciais P, Ellis R, Gloor M, Peylin P, Piao SL, Le Quéré C, Smith B, Zhu Z, Myneni R. 2015. Recent trends and drivers of regional sources and sinks of carbon dioxide. Biogeosciences 12:653-79.

Sitch S, Smith B, Prentice IC, Arneth A, Bondeau A, Cramer W, Kaplan JO, Levis S, Lucht W, Sykes MT, Thonicke K, Venevsky S. 2003. Evaluation of ecosystem dynamics, plant 
geography and terrestrial carbon cycling in the LPJ dynamic global vegetation model. Glob Chang Biol 9:161-85.

Tolwinski-Ward SE, Evans MN, Hughes MK, Anchukaitis KJ. 2010. An efficient forward model of the climate controls on interannual variation in tree-ring width. Clim Dyn 36:2419-39.

Wieser G, Matyssek R, Luzian R, Zwerger P, Pindur P, Oberhuber W, Gruber A. 2009. Effects of atmospheric and climate change at the timberline of the Central European Alps. Ann For Sci 66:402.

Wigley TML, Briffa KR, Jones PD. 1984. On the average value of correlated time series, with applications in dendroclimatology and hydrometeorology. J Clim Appl Meteorol 23:201-13.
Zhang Z, Zimmermann NE, Kaplan JO, Poulter B. 2016. Modeling spatiotemporal dynamics of global wetlands: comprehensive evaluation of a new sub-grid TOPMODEL parameterization and uncertainties. Biogeosciences 13:1387408.

Zhao M, Running SW. 2010. Drought-induced reduction in global terrestrial net primary production from 2000 through 2009. Science 329:940-3.

Zobler L. 1986. A world soil file for global climate modeling: National Aeronautics and Space Administration. New York: Goddard Space Flight Center, Institute for Space Studies. 